\title{
Сравнительные исследования возрастной и временной динамики кефалометрических признаков и антропологическая фотография у современных тувинских школьников при экологических изменениях в популяциях
}

\author{
Андрей М. Маурер, Валерий А. Бацевич, Екатерина Ю. Пермякова, Оксана В. Ясина \\ Московский государственный университет имени М. В. Ломоносова, Российская Федерация
}

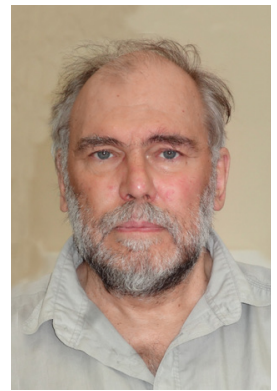

В статье представлены результаты сравнительного изучения возрастной и временной динамики кефалометрических признаков у тувинцев школьного возраста - населения Тувы в 1978 и 2018-2019 г2. Главная задача заключалась в оценке возрастной и временной изменчивости краниометрических признаков в тувинских популяциях в современных условиях.

Сбор антропологических данных детей 6-17 лет был осуществлен по стандартной методике и проходил в одной из национальных школ г. Кызыла (414 человек) и п. Тоора-Хем (341 человек). Все обследованные также были сфотографированы согласно принятой в НИИ и Музее антропологии Московского государственного университета им. М. В. Ломоносова методике И. В. Перевозчикова (1987). К полученным фотографиям был применен метод обобщенного портрета, упростивший визуализацию половой, возрастной и этно-территориальной изменчивости обследованного контингента.
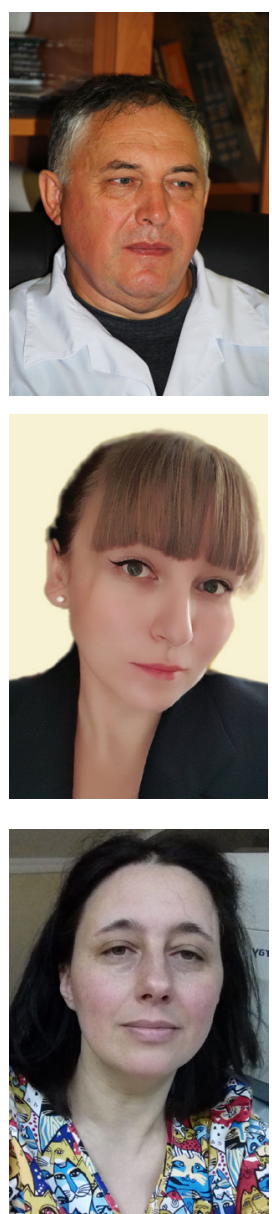

Результаты показали, что динамика изменений размеров головы и лица городских и сельских детей и подростков обоего пола соответствует общебиологическим закономерностям: относительно небольшая интенсивность изменчивости большинства показателей демонстрирует увеличение на протяжении возрастного ряда (за исключением головного указателя). Сравнение этих данных с более ранними (1978 г.) позволяет сделать вывод об отсутствии значимых межпоколенных различий. Отсюда можно заключить, что основные параметры головы и лица, присущие тувинскому этносу, сохраняются на протяжении прошедших со времени последнего обследования десятилетий (только продольный диаметр головы дает незначительный вклад в трансформацию расового и этнического облика населения). Сохранение классических характеристик цеентрально-азиатского типа подтверждают и результаты фотообобщений, что также свидетельствует о значительной гомогенности обследованных тувинских групп в настоящее время.

Ключевые слова: антропоэкология; детское население; кефалометрические признаки; обобщенный фотопортрет; Тува; тувинцы

Работа выполнена при финансовой поддержке РФФИ, грант № 18-09-00417 «Новые антропоэкологические исследования в Республике Тыва. Мониторинг адаптивных процессов через 40 лет», а также в рамках НИР № AAAA-A19-119013090163-2 «Антропология евразийских популяций»).

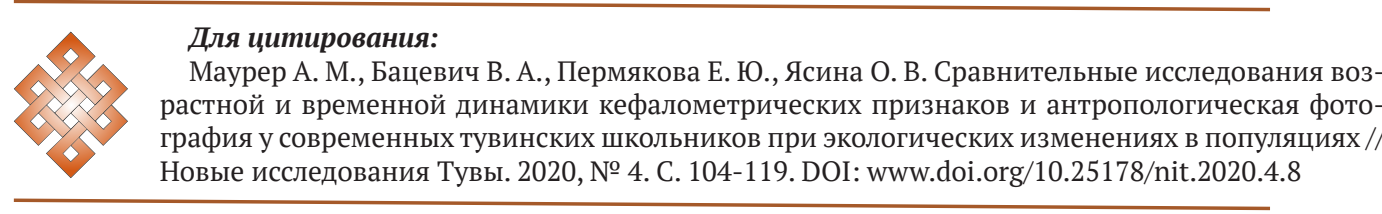

Маурер Андрей Маркович - кандидат биологических наук, старший научный сотрудник Научно-исследовательского института и Музея антропологии Московского государственного университета имени М. В. Ломоносова. Адрес: 125009, Россия, г. Москва, ул. Моховая, д. 11. Тел.: +7 (917) 383-11-11. Эл. адрес: foto-rer@ yandex.ru

Бацевич Валерий Анатольевич - кандидат биологических наук, ведущий научный сотрудник Научноисследовательского института и Музея антропологии Московского государственного университета имени М. В. Ломоносова. Адрес: 125009, Россия, г. Москва, ул. Моховая, д. 11. Тел.: +7 (977) 494-36-32. Эл. адрес: batsevich53@mail.ru

Пермякова Екатерина Юрьевна - кандидат биологических наук, научный сотрудник Научно-исследовательского института и Музея антропологии Московского государственного университета имени М. В. Ломоносова. Адрес: 125009, Россия, г. Москва, ул. Моховая, д. 11. Тел.: +7 (906) 736-31-20. Эл. адрес: ekaterinapermyakova@gmail.com

Ясина Оксана Валерьевна - эколог Научно-исследовательского института и Музея антропологии Московского государственного университета имени М. В. Ломоносова. Адрес: 125009, Россия, г. Москва, ул. Моховая, д. 11. Тел.: +7 (903) 68816-02. Эл. адрес: okyasina@yandex.ru 


\title{
A comparative study of age and temporal dynamics of cephalometric characteristics and anthropological photography in modern Tuvan schoolchildren under environmental changes in populations
}

\author{
Andrey M. Maurer, Valery A. Batsevich, Ekaterina Yu. Permiakova, Oksana V. Yasina \\ Lomonosov Moscow State University, Russian Federation
}

\begin{abstract}
The article aims to compare the age and temporal dynamics of cephalometric characteristics in the Tuvan school population in 1978 and 2018-2019. Our main objective was to assess the age and temporal variability of craniometric characteristics in Tuvan populations under contemporary conditions.

Anthropological data was collected from Tuvan children aged 6-17, according to the standard method, in one of the ethnic schools in Kyzyl (414 people) and Toora-Khem (341 Tozhu Tuvans). All those examined were also photographed according to the method of anthropological photography adopted at the Research Institute and Museum of Anthropology of Moscow State University. The generalized portrait method was applied to the photographs obtained, which simplified the visualization of the sex, age and ethno-territorial variability of the surveyed contingent.

The results obtained showed that the dynamics of changes in the size of the head and face of urban and rural children and adolescents of both genders corresponds to general biological patterns: the relatively low intensity of variability of most indicators demonstrates an increase throughout the age series (except for the cephalic index). Comparison of these data with earlier ones (1978) allows us to conclude that there are no significant intergenerational differences. This is the reason that the main characteristics of the head and face inherent in the Tuvan ethnic group have been preserved over the decades since the last survey (the longitudinal diameter of the head alone does not make an significant contribution to the transformation of the racial and ethnic appearance of the population). The retention of the classical characteristics of the Central Asian type is also confirmed by the results of generalizations of the photographs, which also indicates a significant homogeneity of the studied Tuvan groups at the present time.
\end{abstract}

Keywords: anthropoecology; child population; cephalometric characteristics; composite portraits; Tuva; Tuvans

\section{Financing}

This work was supported by the RFBR grant No. 18-09-00417 «New anthropoecological studies in the Tuva Republic. Monitoring of the adaptive processes in 40 years» and partly by the research project № AAAA-A19-119013090163-2 “Anthropology of Eurasian populations".

\section{For citation:}

Maurer A. M., Batsevich V. A., Permiakova E. Yu. and Yasina O. V. Sravnitel'nye issledovaniia vozrastnoi i vremennoi dinamiki kefalometricheskikh priznakov i antropologicheskaia fotografiia u sovremennykh tuvinskikh shkol'nikov pri ekologicheskikh izmeneniiakh v populiatsiiakh [A comparative study of age and temporal dynamics of cephalometric characteristics and anthropological photography in modern Tuvan schoolchildren under environmental changes in populations]. New Research of Tuva, 2020, no. 4, pp. 104-119. (In Russ.). DOI: www.doi.org/10.25178/nit.2020.4.8

MAURER, Andrey Markovich, Candidate of Biology, Senior Research Fellow, Institute and Museum of Anthropology, Lomonosov Moscow State University. Postal address: 11 Mokhovaya St., 125009 Moscow, Russian Federation. Tel.: +7 (917) 383-11-11. E-mail: fotorer@yandex.ru

ORCID ID: 0000-0002-2607-1558

BATSEVICH, Valery Anatol'evich, Candidate of Biology, Leading Research Fellow, Institute and Museum of Anthropology, Lomonosov Moscow State University. Postal address: 11 Mokhovaya St., 125009 Moscow, Russian Federation. Tel.: +7 (977) 494-36-32. E-mail: batsevich53@mail.ru ORCID ID: 0000-0003-3833-1588

PERMIAKOVA, Ekaterina Yurievna, Candidate of Biology, Research Fellow, Institute and Museum of Anthropology, Lomonosov Moscow State University. Postal address: 11 Mokhovaya St., 125009 Moscow, Russian Federation. Tel.: +7 (906) 736-31-20. E-mail: ekaterinapermyakova@gmail.com ORCID ID: 0000-0002-6490-4004

YASINA, Oksana Valer'evna, Ecologist, Institute and Museum of Anthropology, Lomonosov Moscow State University. Postal address: 11 Mokhovaya St., 125009 Moscow, Russian Federation. Tel.: +7 (903) 688-16-02. E-mail: okyasina@yandex.ru 


\section{Введение}

Антропологическое изучение современного населения Тувы было начато в 1926 г. экспедицией под руководством В. В. Бунака, когда сотрудники Тувинской этнографо-антропологической экспедиции работали как в степных районах, так и в таёжной Тодже (Bunak, 1928). Некоторые итоги этих начальных исследований представлены в работах А. И. Ярхо (Ярхо, 1929, 1936, 1947). Сбор материалов в Туве был продолжен в 1950-1980 гг. несколькими коллективами ученых под руководством М. Г. Левина, Ю. Г. Рычкова, В. И. Богдановой. Подробные сведения о руководителях и местах работы экспедиций, целях, задачах и итогах, выполненных за этот период антропологических исследований можно найти в обзорной статье Г. А. Аксяновой, посвящённой, главным образом, истории поездок и основным выводам, полученным при изучении этногенеза тувинцев (Аксянова, 2009). До 60-х годов XX века все обследования проводились по классической расоведческой программе для решения задач происхождения и внутриэтнической дифференциации тувинского населения. Позднее программа была расширена благодаря дополнительному сбору данных по дерматоглифике, одонтологии и группам крови (Богданова, Халдеева, 1980; Богданова, 1986).

В 1976-1979 гг. сотрудниками Научно-исследовательского института и музея антропологии Московского государственного университета им. М. В. Ломоносова (НИИ антропологии МГУ) под руководством Т. И. Алексеевой было проведено комплексное экспедиционное антропоэкологическое обследование коренного населения в четырех районах (теперь - кожуунах) Тувы: Дзун-Хемчикском, Тоджинском, Монгун-Тайгинском и Эрзинском. Впервые были собраны обширные данные о морфофизиологическом статусе сельского коренного тувинского населения в 4 географических и климатических зонах. В программу исследований входили: антропологические измерения тела (около 40 признаков), кефалометрия и кефалоскопия (измерения и описания признаков головы и черепа), антропологическая фотография, рентгенография костей скелета кисти, дерматоглифика, сбор одонтологических данных, общий анамнез, физиологические показатели (определялся уровень окислительных процессов методом оксигемометрии, кровяное давление, минерализация скелета и др.), элементы демографии (по данным ЗАГСа). Кроме того, был осуществлен сбор образцов крови и волос для получения биохимических и генетических данных, а также для оценки пигментации и микроэлементного состава. Обследовалось, в основном, взрослое население. В двух районах, Монгун-Тайгинском и Тоджинском, по сокращенной программе было проведено морфологическое обследование детского населения школьного возраста.

Этот регион Центральной Азии был выбран для определения биологических характеристик в популяциях, сформировавшихся в условиях резко выраженного континентального климата. В результате сравнительного анализа полученных данных было установлено, что ведущими факторами среды на этой территории являются холодовой стресс, высота над уровнем моря и количество осадков. В ходе проведенных исследований был выявлен и описан соответствующий морфофизиологический комплекс, присущий коренному населению разных географических районов Тувы, по сравнению с хакасскими, алтайскими и монгольскими группами (Антропоэкологические исследования ..., 1984 : 75-114; Антропоэкология Центральной ..., 2005: 35-67). Биологическая и культурная адаптация в рассматриваемых тувинских популяциях складывалась в течение длительного времени. Об этом свидетельствуют закономерные географические вариации черт строения тела и функциональных признаков, структура генофонда, тип хозяйства (Алексеева, 1984, 1986; Антропоэкология Центральной ... , 2005: 35-67).

В современных условиях, при относительной стабильности природных факторов, на протяжении примерно полувека, в тувинских группах происходит ускоряющаяся трансформация образа жизни в результате таких инициированных социальными процессами явлений, как урбанизация, миграции, смена традиционного рода занятий и, соответственно, привычной физической нагрузки, типа питания и др. (Анайбан, 2009, 2010).

Переход в указанную новую экологическую нишу требует новой адаптации. Темпы изменений могут быть разными на разных территориях в Туве в зависимости от степени и скорости нарушений гомеостатических связей, а стрессовые биологические реакции могут проявляться уже на протяжении жизни одного поколения. При слишком быстрых изменениях приспособительный процесс вызывает большое напряжение. В результате в популяциях меняются: морфологические и физиологические особенности (изменение тотальных размеров тела, излишнее накопление жировой ткани в одной части популяции и одновременно астенизация в другой); демографические показатели; эпидемиологические 
характеристики (уровень заболеваемости, вклад различных классов болезней). Наиболее важным признаком нарушения баланса со средой обитания, по данным наших исследований, является изменение темпов онтогенеза на всем его протяжении (ускорение созревания и физического развития у детей, старения у взрослых) и связанные с этими процессами модификации морфологических характеристик в популяциях (Бацевич, Бутовская, Кобылянский, 2018).

В связи с наблюдаемыми экологическими изменениями на территории Республики Тыва, особую актуальность приобрело проведение повторных антропоэкологических исследований в тех же самых районах республики, где ранее проводилось обследование населения и дополнительно в г. Кызыле для оценки степени и направления адаптивных изменений в современных тувинских популяциях при модификации социально-экономических условий жизни. Практическая оценка степени адаптации в различных популяциях и динамика её изменений позволит прогнозировать также и общее состояние здоровья коренного населения Тувы в обследуемых районах на всех этапах онтогенеза.

Изучению изменчивости размеров тела в связи с экологическими преобразованиями на различных территориях Ойкумены посвящено большое количество работ (Волкова, 1988; Козлов и др., 2009; Година, 2010; Бацевич, 2016; Shepard, Rode, 1996; Katzmarzyk, Leonard, 1998; Malina, 2004; Barker, Thornburg, 2013; Brüne, Hochberg, 2013; Eriksson et al., 2013; Hermanussen, 2013 и др.). В то же время относительно мало известно об обусловленной экологическими факторами изменчивости антропометрических признаков головы, возрастные и временные изменения которых существенно отличаются от изменений размеров тела, что связано с известным фактом более раннего формирования черепа в онтогенезе человека. Другим важным фактом являются эволюционные особенности формирования черепной коробки и лицевого отдела скелета черепа (Бунак, 1960; Ауль, 1964; Miklashevskaya, 1966,1969 и др.). Так, было показано, что процесс акселерации захватывает и кефалометрические признаки (Миклашевская, 1973). Сопоставление данных по изменению краниологических размеров у русских детей за 25 лет, начиная с 1940 г., показало увеличение всех диаметров головы, но эти данные требуют проверки и уточнения в других расовых и этнических группах и экологических условиях.

Настоящая работа посвящена сравнительному изучению возрастной и временной динамики кефалометрических признаков у школьного населения Тувы в 1978 и 2018-2019 гг.

Основная гипотеза исследований: стабильность темпов онтогенеза и морфогенеза, а также скорость их изменения являются индикатором степени адаптивности современных популяций или маркируют уровень нарушения антропоэкологических связей.

Главная задача работы: оценить возрастную и временную изменчивость краниометрических признаков в тувинских популяциях в современных условиях.

\section{Материал и методы}

В 2018 г. при поддержке гранта РФФИ «ЖНове антропоэкологические исследования в Республике Тыва. Мониторинг адаптивных процессов через 40 лет»» коллективом под руководством В. А. Бацевича проведены антропоэкологические исследования взрослого и детского тувинского населения школьного возраста в г. Кызыле.

Программа обследования, по сути, повторяла ту, по которой были собраны данные в 1976-1979 гг. Из нее были исключены исследования, мало связанные с временной и социально-экологической изменчивостью населения или требующие особых условий сбора и обработки данных, в том числе этических и организационных (дерматоглифика, сбор образцов крови и волос и др.). Дополнительно в программу был включен биоимпедансный анализ для расширенного изучения состава тела человека, организован сбор данных по кистевой динамометрии, измерению дистальных отделов кисти руки, возрасту наступления менархе. Все исследования выполнялись только с добровольного согласия участников (имеющих паспорт) или их родителей, которые заполняли и подписывали форму «Согласие добровольца». Впоследствии данные были деперсонифицированы.

Сбор антропологических данных у тувинских детей 6-17 лет проходил в средней общеобразовательной школе № 2 имени Народного учителя СССР А. А. Алдын-оол г. Кызыла, которая является первой тувинской школой города (1927). Численность обследованных по разным программам немного варьировала. Минимум по морфологической программе составил 414 человек. Обследованное детское население не является в полной мере городским. Предварительный анализ анкет показал, что подавляющее большинство детей родились в сельской местности или в городе после миграции роди- 
телей из сельской местности. Таким образом, основной контингент школьников представляет собой первичное мигрантное население г. Кызыла. Этнический состав учащихся практически однороден, это тувинцы степных районов. Представители других этносов (русские, монголы, киргизы и метисы) составили менее 10 человек и не вошли в выборку.

Детский материал по тувинцам-тоджинцам впервые был собран в сентябре 1978 г. в школе п. ТоораХем Тоджинского р-на Тувы. Некоторые данные (возрастная динамика размеров тела, изучение вкусовой и обонятельной чувствительности) были опубликованы как сравнительные с другими этническими группами (Антропоэкология Центральной ..., 2005), но данные по размерам головы и лица до настоящего момента не анализировались и не публиковались.

В сентябре 2019 г., спустя 41 год, в той же школе п. Тоора-Хем были обследованы около 400 человек, из них 341 тувинец-тоджинец (162 мальчика и 179 девочек). В разработку по кефалометрической программе вошли только уроженцы Тоджинского р-на. Тувинцы-тоджинцы - особая этническая группа тувинцев, говорящая на тоджинском диалекте тувинского языка. В отличие от других скотоводческих тувинских групп, тоджинцы занимаются оленеводством, а также таёжным промыслом (охота, рыболовство, сбор дикоросов) (Вайнштейн, 1961). В недавнем прошлом, в конце XX века, оленеводство у тоджинцев практически сошло на нет, но в настоящее время этот промысел понемногу возрождается. Антропологически тоджинцы имеют ряд отличий по строению тела, лица и пигментации кожи и волос от степного тувинского населения, а по строению тела ближе к другим таёжным группам (тофаларам, амурским эвенкам) (Антропоэкологические исследования ..., 1984: 200).

При измерении признаков на голове для оценки возрастной изменчивости признаков уже в период раннего детства (4-7 лет) приходится иметь дело с величинами значительно меньшего масштаба по сравнению с телом человека и с размерами, иногда не превышающими нескольких сантиметров или миллиметров. Многие точки не имеют точной скелетной привязки. При фиксации инструмента на них требуется соблюсти ряд условий, связанных с усилием нажима и правильным расположением ножек измерительного циркуля. Толщина кожных, мускульных и жировых покровов на голове имеет абсолютно меньшие размеры по сравнению с телом человека, что облегчает задачу измерений, но все же требует выработки стандартной степени нажима на инструмент для достижения требуемых повторяемых результатов.

Все обследованные в двух экспедициях 2018 и 2019 гг. были сфотографированы согласно принятой в НИИ и Музее антропологии МГУ методике антропологической фотографии (Перевозчиков, 1987).

Метод обобщенного портрета, который широко используется в антропологи как научно-иллюстративный и познавательный инструмент (Galton, 1878), применён и в настоящем исследовании. Метод упрощает решение таких задач, как визуализация половой, возрастной и этно-территориальной изменчивости популяций (Перевозчиков, Маурер, 2009).

Создавая обобщённый портрет, антрополог работает с полученными в полевых условиях индивидуальными фотографиями. В результате применения специальных методик происходит преобразование персональных фотоизображений в качественно новый информационный объект. Этот процесс подобен вариационно-статистической обработке первичных измерительных данных.

Прошедшая тестирование в лаборатории расоведения и внедренная в практику компьютерная программа «faceONface» (Савинецкий и др., 2015) позволяет получать цифровые фотообобщения повышенной чёткости путем наложения и сопоставления изображений в норме анфас по трем - 2 зрачковым (pupillion) и ротовой (stomion) - реперным точкам (Маурер, Сыроежкин, 2015).

\section{Результаты}

В таблицах 1-3 представлены возрастные кефалометрические данные, собранные у детей школьного возраста в п. Тоора-Хем Тоджинского р-на в 1978 и 2019 гг.

В таблицах представлены все основные признаки, используемые в расогенетических работах, в том числе дополнительные размеры в окологлазничной области, используемые как реперные точки при антропологической фотографии (всего 18 показателей). В данном исследовании, после предварительного изучения материала, мы выбрали для иллюстрации 2 признака и 1 индекс (графики 1-6). Они характеризуют продольные, широтные и высотные размеры головы и соотношение возрастной и временной изменчивости признаков и с достаточной точностью измеряются. 
Таблица 1. Возрастная динамика размеров головы у тувинцев-тоджинцев школьного возраста из пос. Тоора-Хем. Обследование 1978 г. TTable 1. Age-related dynamics of head sizes in Tozhu Tuvans of school age from the village of Toora-Khem. 1978 survey

\begin{tabular}{|c|c|c|c|c|c|c|c|c|c|c|c|c|c|}
\hline \multirow{2}{*}{$\begin{array}{c}\text { Хрон. } \\
\text { возраст } \\
\text { (лет) }\end{array}$} & \multirow{2}{*}{$N$} & \multicolumn{2}{|c|}{ Продольный диаметр } & \multicolumn{2}{|c|}{ Поперечный диаметр } & \multicolumn{2}{|c|}{ Наименьшая ширина лба } & \multicolumn{2}{|c|}{ Скуловой диаметр } & \multicolumn{2}{|c|}{$\begin{array}{c}\text { Нижнечелюстной } \\
\text { диаметр }\end{array}$} & \multicolumn{2}{|c|}{$\begin{array}{c}\text { Физиономическая } \\
\text { высота лица }\end{array}$} \\
\hline & & $M$ & $S$ & $M$ & $S$ & $M$ & $S$ & $M$ & $S$ & $M$ & $S$ & $M$ & $S$ \\
\hline
\end{tabular}

\section{Мальчики}

\begin{tabular}{|c|c|c|c|c|c|c|c|c|c|c|c|c|c|c|}
\hline 7 & 6 & 174,8 & 4,12 & 145,2 & 4,07 & 101,3 & 3,20 & 121,7 & 3,08 & 93,7 & 3,39 & 167,8 & 2,74 \\
\hline 8 & 5 & 173,0 & 6,60 & 147,6 & 4,16 & 102,8 & 2,86 & 126,2 & 4,60 & 94,8 & 4,97 & 167,8 & 9,47 \\
\hline 9 & 5 & 176,6 & 5,83 & 148,6 & 8,99 & 102,2 & 5,12 & 127,6 & 5,59 & 96,4 & 5,08 & 169,0 & 9,30 \\
\hline 10 & 4 & 176,5 & 3,00 & 145,5 & 4,43 & 103,0 & 4,69 & 125,7 & 1,71 & 96,2 & 2,63 & 167,5 & 6,24 \\
\hline 11 & 28 & 177,7 & 6,05 & 149,9 & 4,68 & 104,1 & 3,87 & 131,1 & 5,38 & 104,6 & 5,94 & 174,9 & 7,97 \\
\hline 12 & 14 & 178,6 & 6,51 & 151,0 & 3,84 & 104,8 & 3,27 & 133,6 & 4,11 & 105,6 & 7,63 & 187,5 & 7,92 \\
\hline 13 & 4 & 176,5 & 5,32 & 153,2 & 1,71 & 107,5 & 1,29 & 134,0 & 3,16 & 104,7 & 3,62 & 184,7 & 9,07 \\
\hline 14 & 7 & 181,3 & 3,59 & 155,6 & 5,16 & 108,8 & 2,61 & 139,3 & 3,09 & 113,3 & 4,57 & 186,7 & 3,04 \\
\hline 15 & 14 & 180,9 & 5,97 & 154,8 & 7,31 & 110,3 & 6,02 & 138,6 & 6,51 & 112,1 & 5,38 & 187,6 & 8,07 \\
\hline 16 & 12 & 182,0 & 5,77 & 152,7 & 6,73 & 107,1 & 6,13 & 137,7 & 5,69 & 110,7 & 7,63 & 191,7 & 9,16 \\
\hline 17 & 13 & 186,1 & 5,53 & 154,8 & 5,51 & 108,4 & 4,48 & 141,3 & 5,81 & 113,4 & 7,13 & 194,4 & 6,56 \\
\hline
\end{tabular}

Девочки

\begin{tabular}{|c|c|c|c|c|c|c|c|c|c|c|c|c|c|}
\hline 7 & 8 & 171,5 & 4,90 & 142,5 & 5,48 & 99,5 & 2,63 & 121,4 & 4,03 & 89,7 & 2,96 & 166,7 & 6,58 \\
\hline 8 & 3 & 169,0 & 4,36 & 147,3 & 6,81 & 100,7 & 4,16 & 124,0 & 4,58 & 96,0 & 2,65 & 160,0 & 4,58 \\
\hline 9 & 3 & 172,3 & 4,04 & 144,3 & 4,51 & 105,7 & 2,08 & 125,0 & 1,00 & 94,7 & 4,04 & 165,0 & 7,21 \\
\hline 10 & 6 & 173,0 & 4,00 & 148,0 & 5,02 & 103,7 & 4,03 & 128,7 & 5,09 & 96,8 & 4,26 & 169,2 & 14,82 \\
\hline 11 & 13 & 171,9 & 5,03 & 147,5 & 6,06 & 103,4 & 4,55 & 130,3 & 8,45 & 101,5 & 6,60 & 174,3 & 10,53 \\
\hline 12 & 14 & 172,4 & 6,42 & 144,6 & 4,75 & 102,7 & 4,95 & 128,1 & 5,06 & 103,9 & 5,47 & 174,9 & 6,17 \\
\hline 13 & 8 & 175,9 & 8,11 & 146,6 & 4,34 & 105,1 & 4,29 & 130,7 & 3,73 & 104,0 & 4,93 & 183,2 & 6,80 \\
\hline 14 & 25 & 178,9 & 6,53 & 149,7 & 5,26 & 106,1 & 3,12 & 136,4 & 5,49 & 107,8 & 6,20 & 184,3 & 6,27 \\
\hline 15 & 14 & 177,7 & 6,01 & 148,8 & 4,20 & 108,0 & 3,35 & 136,0 & 5,28 & 105,7 & 5,93 & 183,6 & 7,16 \\
\hline 16 & 23 & 176,9 & 4,50 & 150,3 & 4,47 & 106,6 & 4,54 & 136,6 & 6,03 & 110,6 & 5,80 & 184,2 & 8,41 \\
\hline 17 & 15 & 178,6 & 6,68 & 152,3 & 5,62 & 108,1 & 5,15 & 138,9 & 5,42 & 110,8 & 6,27 & 188,9 & 5,32 \\
\hline
\end{tabular}



Table 2. Age-related dynamics of head sizes in Tozhu Tuvansof school age from the village of Toora-Khem. 2019 survey

\begin{tabular}{|c|c|c|c|c|c|c|c|c|c|c|c|c|c|}
\hline \multirow{2}{*}{$\begin{array}{c}\text { Возраст } \\
\text { (лет) }\end{array}$} & \multirow{2}{*}{$N$} & \multicolumn{2}{|c|}{ Продольный диаметр } & \multicolumn{2}{|c|}{ Поперечный диаметр } & \multicolumn{2}{|c|}{ Наименьшая ширина лба } & \multicolumn{2}{|c|}{ Скуловой диаметр } & \multicolumn{2}{|c|}{$\begin{array}{c}\text { Нижнечелюстной } \\
\text { диаметр }\end{array}$} & \multicolumn{2}{|c|}{$\begin{array}{c}\text { Физиономическая } \\
\text { высота лица }\end{array}$} \\
\hline & & $M$ & $S$ & $M$ & $S$ & $M$ & $S$ & $M$ & $S$ & $M$ & $S$ & $M$ & $S$ \\
\hline
\end{tabular}

Мальчики

\begin{tabular}{|c|c|c|c|c|c|c|c|c|c|c|c|c|c|}
\hline 7 & 8 & 179,6 & 5,45 & 145,7 & 3,92 & 99,9 & 3,91 & 124,7 & 3,65 & 95,1 & 1,73 & 169,4 & 6,76 \\
\hline 8 & 22 & 178,3 & 7,57 & 145,8 & 4,41 & 103,3 & 2,88 & 126,8 & 4,03 & 97,5 & 4,34 & 167,0 & 8,98 \\
\hline 9 & 6 & 183,7 & 7,92 & 144,0 & 3,41 & 103,3 & 3,01 & 128,7 & 2,80 & 101,3 & 3,08 & 172,8 & 5,84 \\
\hline 10 & 17 & 183,8 & 8,73 & 149,3 & 3,75 & 107,3 & 4,15 & 133,6 & 5,02 & 103,0 & 4,95 & 174,5 & 7,29 \\
\hline 11 & 14 & 185,7 & 5,70 & 149,9 & 6,04 & 105,8 & 3,84 & 133,2 & 3,47 & 103,3 & 3,72 & 178,3 & 11,20 \\
\hline 12 & 17 & 185,2 & 6,33 & 149,5 & 5,18 & 106,5 & 4,54 & 133,6 & 4,23 & 103,9 & 4,15 & 180,0 & 6,89 \\
\hline 13 & 18 & 185,8 & 5,72 & 153,1 & 5,63 & 107,4 & 3,99 & 138,5 & 4,49 & 105,8 & 3,61 & 183,8 & 8,87 \\
\hline 14 & 18 & 185,3 & 7,21 & 152,9 & 6,25 & 108,2 & 4,02 & 137,9 & 5,58 & 105,0 & 4,92 & 183,3 & 7,53 \\
\hline 15 & 26 & 189,8 & 7,22 & 153,6 & 6,96 & 105,9 & 4,17 & 139,8 & 4,19 & 106,2 & 4,55 & 190,3 & 8,70 \\
\hline 16 & 16 & 192,0 & 8,37 & 152,9 & 4,15 & 106,2 & 3,64 & 142,1 & 4,27 & 105,7 & 3,89 & 191,2 & 7,75 \\
\hline 17 & 10 & 193,6 & 5,70 & 153,2 & 4,34 & 107,7 & 2,63 & 143,3 & 3,80 & 107,7 & 4,45 & 193,0 & 9,88 \\
\hline \multicolumn{14}{|c|}{ Девочки } \\
\hline 7 & 12 & 177,1 & 7,28 & 144,6 & 4,29 & 102,8 & 5,56 & 126,5 & 3,90 & 96,8 & 5,49 & 167,9 & 7,86 \\
\hline 8 & 6 & 175,5 & 5,89 & 141,3 & 7,66 & 102,2 & 2,57 & 123,8 & 5,91 & 94,8 & 6,34 & 160,3 & 4,03 \\
\hline 9 & 18 & 180,0 & 5,02 & 145,9 & 5,38 & 105,3 & 3,97 & 128,4 & 4,26 & 100,5 & 4,42 & 170,4 & 5,96 \\
\hline 10 & 28 & 180,2 & 7,74 & 143,7 & 4,19 & 103,8 & 4,74 & 129,4 & 3,91 & 99,4 & 3,97 & 171,5 & 5,71 \\
\hline 11 & 18 & 183,4 & 4,08 & 146,9 & 6,19 & 106,0 & 4,34 & 132,4 & 5,10 & 101,3 & 5,19 & 181,4 & 6,54 \\
\hline 12 & 22 & 179,1 & 7,32 & 144,7 & 5,52 & 103,0 & 4,60 & 131,7 & 4,37 & 99,9 & 3,94 & 179,5 & 9,47 \\
\hline 13 & 13 & 184,4 & 4,21 & 150,2 & 5,70 & 107,3 & 5,98 & 137,1 & 6,16 & 103,9 & 4,05 & 183,1 & 7,89 \\
\hline 14 & 24 & 181,2 & 6,94 & 146,5 & 5,22 & 103,9 & 4,93 & 135,4 & 4,62 & 104,6 & 5,53 & 183,9 & 8,23 \\
\hline 15 & 24 & 181,5 & 4,96 & 147,4 & 4,77 & 103,5 & 4,15 & 134,7 & 3,97 & 102,8 & 2,28 & 187,3 & 7,32 \\
\hline 16 & 18 & 186,5 & 6,07 & 148,0 & 5,07 & 103,8 & 4,85 & 137,5 & 4,17 & 103,5 & 4,44 & 188,9 & 6,36 \\
\hline 17 & 11 & 183,6 & 6,61 & 149,6 & 3,91 & 105,2 & 3,37 & 137,5 & 4,01 & 104,7 & 4,80 & 187,7 & 6,86 \\
\hline
\end{tabular}


Таблица 3. Возрастная динамика размеров головы у тувинцев школьного возраста из г. Кызыл. Обследование 2018 г. Table 3. Age dynamics of head sizes in school-age Tuvans from Kyzyl. 2018 Survey

\begin{tabular}{|c|c|c|c|c|c|c|c|c|c|c|c|c|c|}
\hline \multirow{2}{*}{$\begin{array}{l}\text { Возраст } \\
\text { (лет) }\end{array}$} & \multirow{2}{*}{$N$} & \multicolumn{2}{|c|}{ Продольный диаметр } & \multicolumn{2}{|c|}{ Поперечный диаметр } & \multicolumn{2}{|c|}{$\begin{array}{c}\text { Наименьшая ширина } \\
\text { лба }\end{array}$} & \multicolumn{2}{|c|}{ Скуловой диаметр } & \multicolumn{2}{|c|}{$\begin{array}{c}\text { Нижнечелюстной } \\
\text { диаметр }\end{array}$} & \multicolumn{2}{|c|}{$\begin{array}{c}\text { Физиономическая } \\
\text { высота лица }\end{array}$} \\
\hline & & $M$ & $S$ & $M$ & $S$ & $M$ & $S$ & $M$ & $S$ & $M$ & $S$ & $M$ & $S$ \\
\hline
\end{tabular}

Мальчики

\begin{tabular}{|c|c|c|c|c|c|c|c|c|c|c|c|c|c|}
\hline 7 & 2 & 169,5 & - & 143,5 & - & 104,0 & & 126,0 & - & 91,0 & - & 159,0 & - \\
\hline 8 & 18 & 180,7 & 5,31 & 147,9 & 5,72 & 108,2 & 3,85 & 130,8 & 4,47 & 101,2 & 3,76 & 170,4 & 5,48 \\
\hline 9 & 25 & 180,2 & 4,34 & 150,3 & 3,69 & 107,0 & 3,80 & 131,8 & 3,19 & 101,2 & 3,29 & 173,7 & 6,21 \\
\hline 10 & 21 & 184,9 & 6,59 & 148,5 & 4,03 & 106,4 & 4,46 & 133,3 & 4,77 & 103,8 & 4,75 & 176,6 & 8,01 \\
\hline 11 & 24 & 188,2 & 6,47 & 151,1 & 5,13 & 109,7 & 4,82 & 136,9 & 4,87 & 106,1 & 5,24 & 178,6 & 8,70 \\
\hline 12 & 22 & 184,2 & 6,94 & 152,1 & 5,82 & 108,6 & 3,23 & 137,1 & 4,32 & 104,3 & 4,24 & 178,8 & 6,66 \\
\hline 13 & 18 & 185,9 & 9,81 & 151,0 & 4,98 & 108,3 & 5,32 & 137,2 & 4,67 & 106,9 & 4,73 & 182,6 & 8,44 \\
\hline 14 & 21 & 187,7 & 6,34 & 154,0 & 7,11 & 109,7 & 5,25 & 141,7 & 7,02 & 108,1 & 5,27 & 188,1 & 6,80 \\
\hline 15 & 28 & 189,8 & 7,28 & 153,8 & 4,11 & 109,5 & 4,43 & 141,6 & 4,76 & 108,5 & 5,60 & 190,1 & 5,84 \\
\hline 16 & 8 & 194,1 & 4,45 & 157,0 & 4,21 & 112,2 & 3,54 & 147,1 & 6,38 & 113,1 & 3,44 & 197,2 & 5,12 \\
\hline 17 & 7 & 194,3 & 6,10 & 157,1 & 6,01 & 111,3 & 4,64 & 146,4 & 6,08 & 110,8 & 6,20 & 193,3 & 8,98 \\
\hline 18 & 11 & 195,8 & 6,71 & 157,6 & 5,82 & 110,8 & 3,49 & 148,2 & 4,87 & 113,9 & 3,05 & 196,5 & 9,85 \\
\hline \multicolumn{14}{|c|}{ Девочки } \\
\hline 7 & 14 & 174,5 & 6,59 & 144,1 & 6,19 & 103,1 & 4,92 & 126,3 & 4,50 & 98,3 & 4,34 & 167,2 & 6,20 \\
\hline 8 & 19 & 179,2 & 6,03 & 145,8 & 7,04 & 104,8 & 4,17 & 128,4 & 6,00 & 99,8 & 4,02 & 171,2 & 7,32 \\
\hline 9 & 21 & 178,7 & 5,98 & 144,6 & 4,98 & 103,7 & 3,40 & 128,4 & 4,50 & 99,4 & 3,81 & 171,5 & 6,39 \\
\hline 10 & 20 & 181,2 & 5,79 & 146,5 & 4,84 & 106,2 & 4,89 & 132,0 & 5,49 & 100,8 & 4,29 & 177,7 & 8,42 \\
\hline 11 & 24 & 178,6 & 5,16 & 148,3 & 4,55 & 105,9 & 3,26 & 132,3 & 5,02 & 102,4 & 3,70 & 175,0 & 5,00 \\
\hline 12 & 28 & 181,5 & 4,97 & 148,1 & 5,38 & 107,4 & 6,30 & 135,4 & 4,80 & 103,4 & 4,54 & 181,6 & 7,46 \\
\hline 13 & 20 & 180,1 & 7,31 & 149,6 & 5,90 & 106,4 & 4,52 & 136,4 & 5,45 & 104,0 & 4,88 & 179,5 & 8,38 \\
\hline 14 & 20 & 182,0 & 6,88 & 149,6 & 4,99 & 106,5 & 4,26 & 137,3 & 4,72 & 104,9 & 3,91 & 184,2 & 8,44 \\
\hline 15 & 22 & 184,5 & 4,66 & 149,9 & 4,70 & 108,4 & 4,28 & 138,2 & 5,85 & 106,3 & 4,44 & 187,4 & 6,82 \\
\hline 16 & 19 & 182,7 & 7,48 & 149,7 & 6,68 & 108,2 & 4,43 & 138,6 & 5,22 & 105,7 & 6,04 & 184,3 & 6,20 \\
\hline 17 & 10 & 186,3 & 6,95 & 151,3 & 4,37 & 109,1 & 3,63 & 139,4 & 4,88 & 108,2 & 6,21 & 186,2 & 9,15 \\
\hline 18 & 7 & 182,0 & 4,43 & 150,8 & 7,82 & 106,6 & 4,24 & 139,4 & 4,79 & 107,1 & 3,44 & 185,1 & 4,18 \\
\hline
\end{tabular}


На основании данных, полученных из представленных таблиц и продублированных на графиках, мы можем с большой долей вероятности, сделать следующие заключения:

По величине продольного диаметра головы в рассматриваемом возрастном интервале не обнаружена дифференциация между двумя тувинскими детскими группами, обследованными в 2018 г. в г. Кызыле и в 2019 г. в Тоджинском р-не. Возрастные изменения продольного диаметра в этих группах составили приблизительно 15 мм у мальчиков о около 10 мм у девочек (табл. 1-3; графики 3-4);

При межгрупповом сравнении наблюдаются статистически достоверные отличия между двумя, обследованными в 2018 и 2019 гг. группами и третьей, изученной в 1978 г. в Тоджинском p-не (p<0,005). Тувинцы-тоджинцы 1978 г. измерения имели значения продольного диаметра головы, в среднем, на 11-13 мм меньше на протяжении всего изучаемого возрастного интервала у обоих полов (табл. 1-3; графики 3-4);

Мальчики

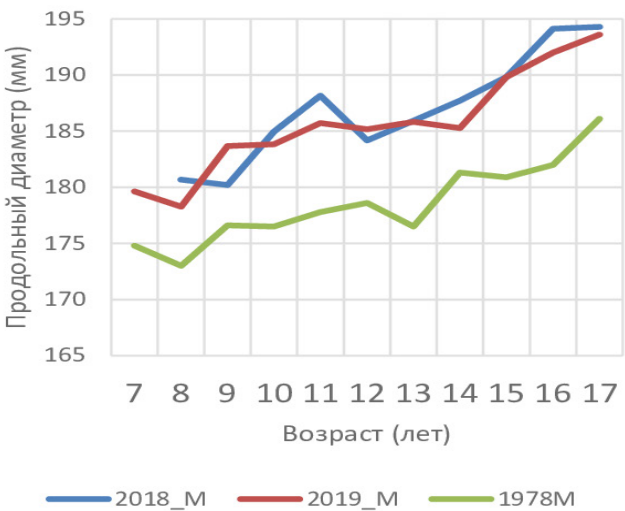

Девочки

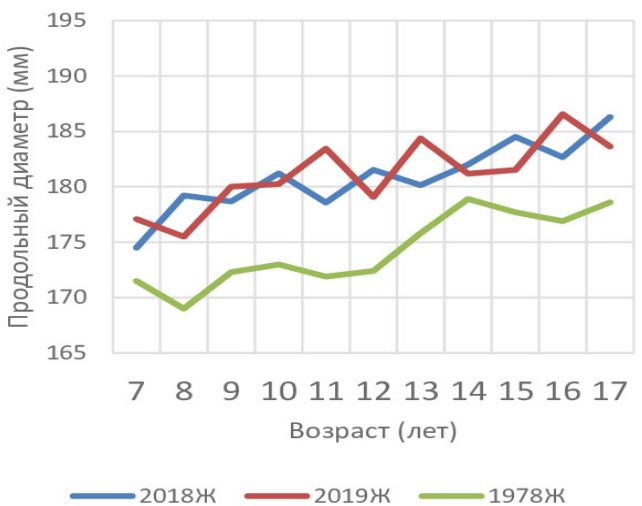

Графики 1 и 2. Динамика возрастных изменений продольного диаметра головы в трех обследованных группах.

Graphs 1 and 2. Dynamics of age-related changes in head longitudinal diameters in the three surveyed groups.

По общим величинам и возрастной динамике поперечного диаметра головы все три сравниваемые группы (обследованные в 1978, 2018 и 2019 гг.), не показали достоверных различий (табл. 1-3; графики 5-6). Из этого наблюдения можно сделать вывод, что в изученных тувинских детских группах не происходило заметных временных изменений поперечного диаметра головы. Возрастное увеличение этого показателя составляет, в среднем, около 8-9 мм у мальчиков и примерно 5-7 мм, у девочек;

Мальчики

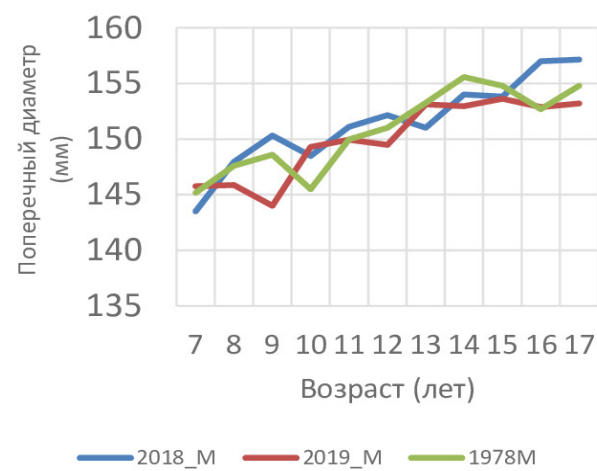

Девочки

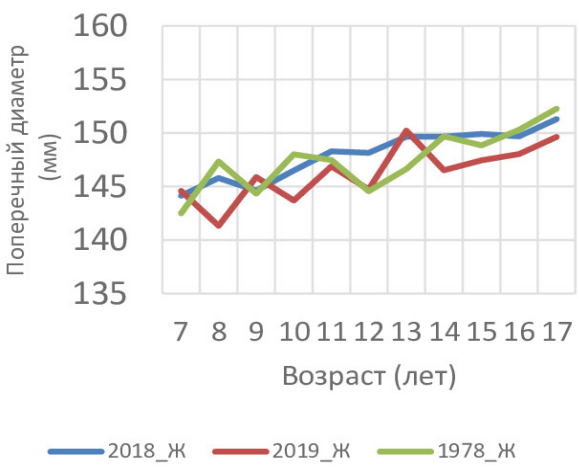

Графики 3 и 4. Динамика возрастных изменений поперечного диаметра головы в трех обследованных группах. Graphs 3 and 4. Dynamics of age-related changes in head transverse diameters in the three surveyed groups. 
Головной указатель, который вычисляется как отношение поперечного диаметра головы к продольному, сохранил свое значение в районе 85 единиц в группе тувинцев-тоджинцев 1978 года обследования, что соответствует значениям во взрослой группе, обследованной в 1977 г. в Тоджинском районе (табл. 1-3; графики 5-6). В детских группах тувинцев - тоджинцев 2019 г. и у тувинцев, обследованных в г. Кызыле, головной указатель составил приблизительно 81, что примерно на 2 единицы ниже, чем в 4 взрослых группах тувинцев, обследованных в 1976-1978 гг. (Алексеева, 1984: 85). По полу и возрасту в детских группах головной указатель, по нашим данным, направленно не изменяется;

Мальчики

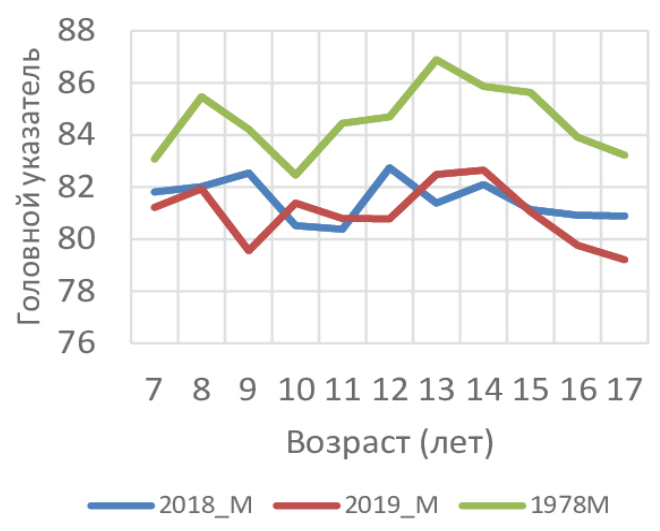

Девочки

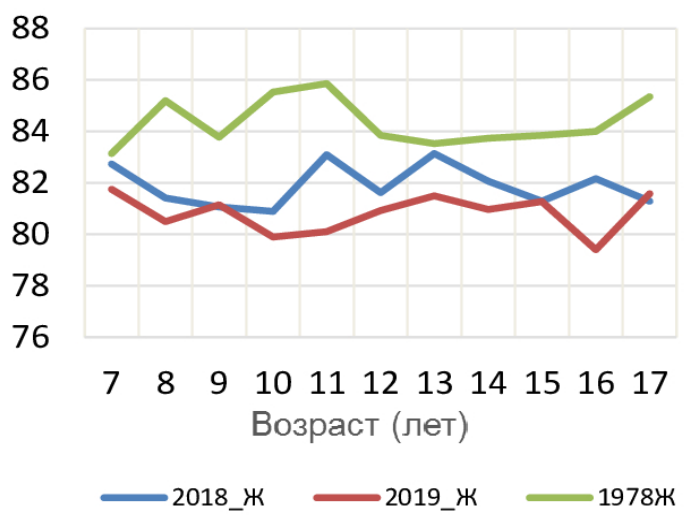

Графики 5-6. Динамика возрастных изменений головного указателя в трех обследованных группах. Graphs 5 and 6. Dynamics of age-related changes in cephalic index in the three surveyed groups.

Такие широтные признаки, как скуловой и нижнечелюстной диаметры, близки по своим значениям во всех трех группах (табл. 1-3);

Морфологическая высота лица показывает незначительные временные изменения и схожую возрастную динамику в группах с акселерацией развития (2018 и 2019 гг. обследования) и без таковой (группа 1978 г. обследования). Эта разница наблюдается в виде тенденции у обоих полов и статистически не подтверждается. Вероятно, это связано со слабой возрастной изменчивостью высотных размеров лица и черепа у детей после 4 лет, в том числе в популяциях с акселерацией развития (табл. 1-3).

Для наглядной иллюстрации возрастной динамики изменений пропорций лица (по измерительным признакам), а также для подтверждения однородности тувинских выборок по расовому (описательному, качественному) комплексу признаков в настоящем исследовании использованы серии обобщённых фотопортретов в 25-30 изображений. Авторами были использованы достаточные выборки по произвольно выбранным возрастным интервалам с целью сокращения объёма статьи (7-9, 10-12 и 15-17 лет), представленные на фотографиях 1-6.

\section{Обсуждение результатов}

Согласно литературным данным, наблюдаемые популяционно-демографические сдвиги в Республике Тыва в последние десятилетия указывают на динамику практически всех показателей образа жизни и здоровья населения. Так, подтверждены смена рода занятий и высокая безработица среди сельского населения, миграция представителей молодого поколения в города (Анайбан, 2009). Найден низкий общий индекс популяционного здоровья, являющийся причиной высокой детской смертности в регионе (Будилова, Лагутин, Мигранова, 2015). Продолжительность жизни в Туве остается одной из самых низких в стране. По данным министерства здравоохранения Республики Тыва, болезни сердечно-сосудистой системы находятся на первом месте по распространенности и смертности среди населения ${ }^{1}$.

${ }^{1}$ Социально-экономическое положение Республики Тыва в январе-феврале 2019 года [Электронный ресурс] // Управление Федеральной службы государственной статистики по Красноярскому краю, Республике Хакасия и Республике Тыва. URL: https://krasstat.ru/doklad/Tuva/4/dok.htm (дата обращения: 10.11.2019). 


\section{НОВЫЕ ИССЛЕДОВАНИЯ ТУВЫ}

www.nit.tuva.asia
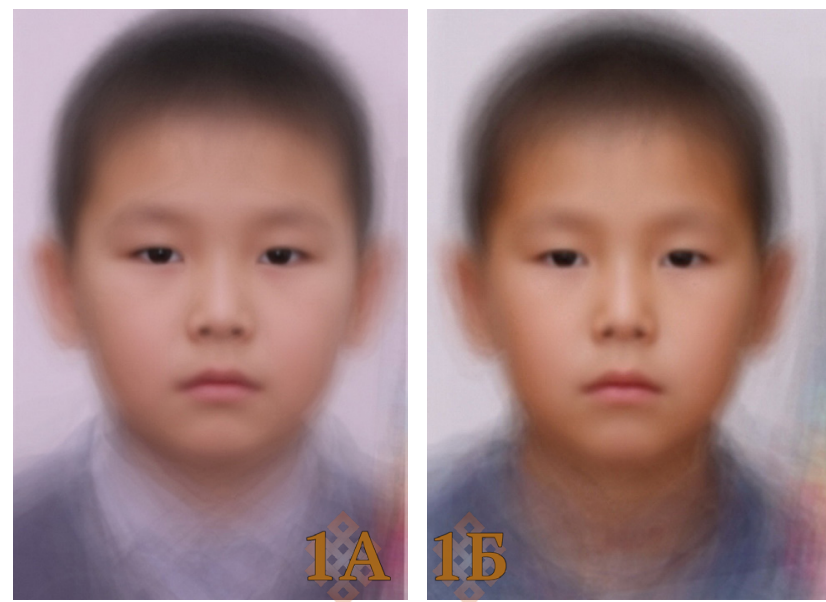

Фото 1. Обобщенный фотопортрет 7-9-летних мальчиков

2. Кызыла (А) и п. Тоора-Хем (Б). Фото А. М. Маурера, 2018-2019 г2. Photo 1. A composite portrait of 7-9-year-old boys from Kyzyl (A) and Toora-Khem (Б). Photo by A. M. Maurer, 2018-2019.
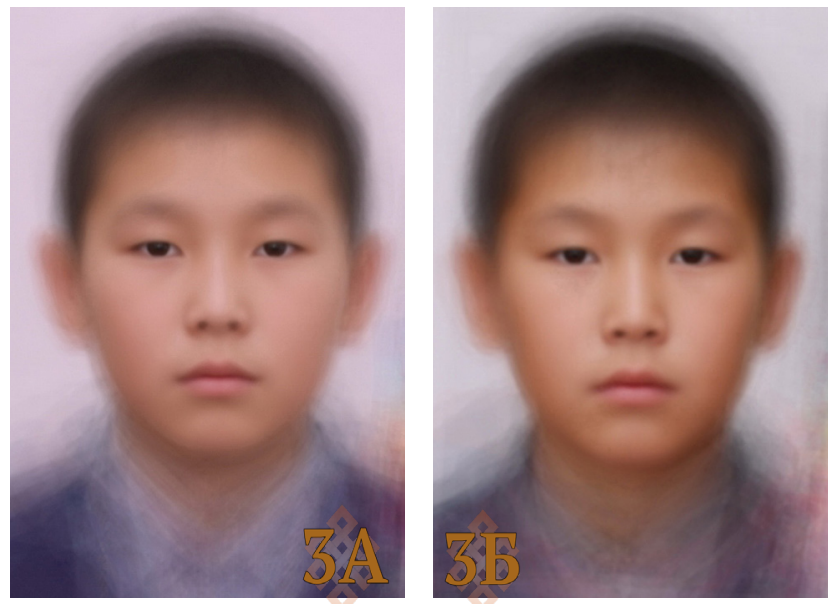

Фото 3. Обобщенный фотопортрет 10-12-летних мальчиков 2. Кызыла (А) и п. Тоора-Хем (Б).

Фото A. M. Maypepa, 2018-2019 22.

Photo 3. A composite portrait of 10-12-year-old boys from Kyzyl (A) and Toora-Khem (Б). Photo by A. M. Maurer, 2018-2019.
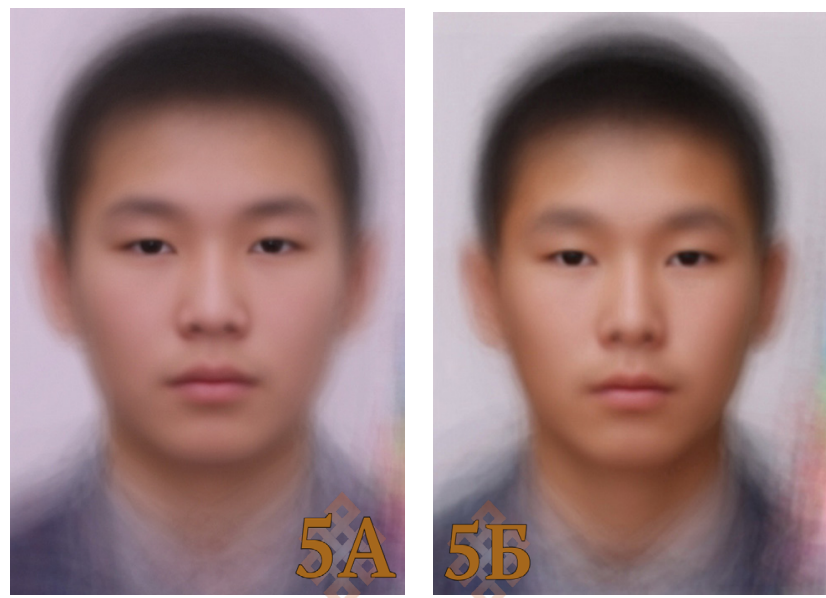

Фото 5. Обобщенный фотопортрет 16-17-летних мальчиков 2. Кызыла (А) и п. Тоора-Хем (Б). Фото А. М. Маурера, 2018-2019.

Photo 5. A composite portrait of 16-17-year-old boys from Kyzyl (A) and Toora-Khem (Б). Photo by A. M. Maurer, 2018-2019.
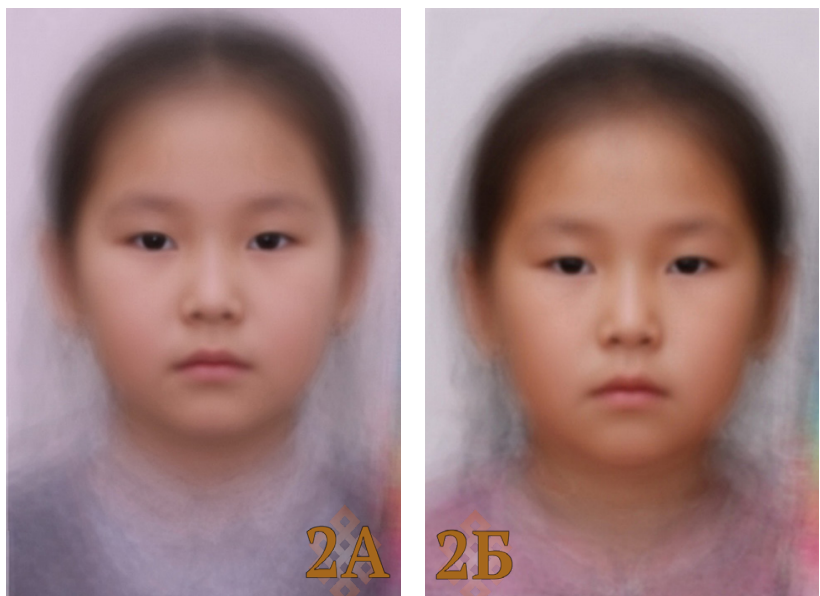

Фото 2. Обобщенный фотопортрет 7-9-летних девочек

2. Кызыла (А) и п. Тоора-Хем (Б).

Фото А. М. Маурера, 2018-2019 г2.

Photo 2. A composite portrait of 7-9-year-old girls from Kyzyl (A) and Toora-Khem (Б). Photo by A. M. Maurer, 2018-2019.

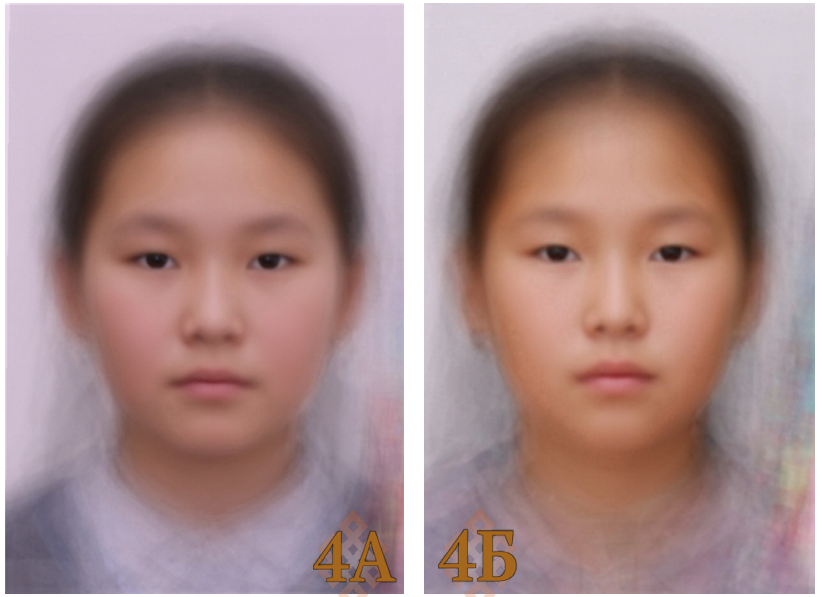

Фото 4. Обобщенный фотопортрет 10-12-летних девочек 2. Кызыла (А) и п. Тоора-Хем (Б).

Фото A. M. Маурера, 2018-2019 22.

Photo 4. A composite portrait of 10-12-year-old girls from Kyzyl (A) and Toora-Khem (Б). Photo by A. M. Maurer, 2018-2019.
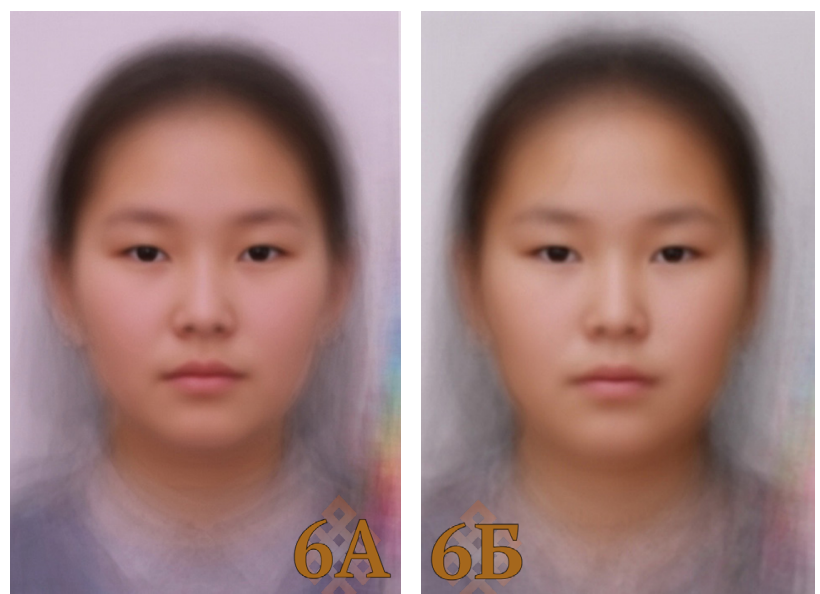

Фото 6. Обобщенный фотопортрет 16-17-летних девочек 2. Кызыла (А) и п. Тоора-Хем (Б) Фото А. М. Маурера, 2018-2019.

Photo 6. A composite portrait of 16-17-year-old girls from Kyzyl (A) and Toora-Khem (Б). Photo by A. M. Maurer, 2018-2019. 
Как было показано в нашей предыдущей работе (Бацевич, Машина, Пермякова, 2020), социальноэкономические преобразования на территории Тувы явились причиной изменения привычного образа жизни, физических нагрузок, питания, социальных функций и, соответственно, адаптивных биологических характеристик у коренного населения, которые в течение длительного времени до этого сохранялись стабильными. В частности, у детского населения Тоджинского р-на за 41 год (1978-2019 гг.) увеличились продольные и поперечные размеры тела и ускорились темпы развития морфологических признаков. Об ускорении темпов онтогенеза свидетельствует и средний возраст менархе у тоджинских девочек школьного возраста. По материалам 2019 г. он составил 13,0 лет и снизился на 0,9 года по сравнению с данными 1978 г. Адаптивные морфофизиологические изменения происходят на всей территории Тувы и не ограничиваются только Тоджинским р-ном (Бацевич, Красильникова, Пермякова 2020).

Таким образом, такие явления, как акселерация развития и секулярный тренд, до 1980-х годов практически не отмечавшиеся в этом регионе, сейчас обнаруживаются на всей территории Республики Тыва. Некоторые тенденции ускорения онтогенеза до этого можно было наблюдать только в одном из 4 обследованных в 1976-1978 гг. районах - Дзун-Хемчикском. Этот район выделялся по ускоренным темпам накопления возрастных изменений на костях скелета кисти (Бацевич, Ясина, 2000).

Что касается размеров головы, то, как известно из литературных источников, к 4 годам эти показатели у детей достигают примерно от 80 до 90\% величины в 18 лет. Степень созревания значительно отличается у продольных, широтных и высотных размеров лица и черепа. Например, прирост длины головы от рождения до года соответствует приросту от года до 18 лет. Еще быстрее растет за этот период широтный диаметр (Миклашевская, 1973). Данные наблюдения означают, что в изучаемом нами возрастном диапазоне 7-17 лет интенсивность возрастной изменчивости признаков будет различна и достаточно мала, как это видно из табл. 1-3. Особенно это касается признаков носовой и глазной области. Но как минимум до 17 лет, конечной возрастной точки наших наблюдений, увеличение размерных признаков головы постепенно, хотя и очень медленно, продолжается (графики 1-6, табл. 1-3). Это не касается головного указателя, который, с возрастом немного уменьшается (графики 5-6), что согласуется с наблюдениями, выполненными на обширных материалах по детям разных рас, опубликованными ранее. Продольный диаметр черепа продолжает расти после прекращения роста поперечного диаметра (Миклашевская, 1973).

Именно по причине выраженной возрастной неравномерности роста размеров лица и черепа, головные признаки менее удобны для наблюдения и фиксации возрастных процессов при изучении роста и развития человека по сравнению с размерами тела. Размеры и форма головы практически не изменяются и при акселерации развития. Из полученных данных можно сделать вывод, что только продольный диаметр головы может дать незначительный вклад в трансформацию расового и этнического облика населения. Очевидно, что благодаря этим свойствам сохраняются основные черты, присущие каждому этносу.

Что касается серии обобщенных фотопортретов, то при значительном индивидуальном физиономическом разнообразии детей смешанной городской и сельской тоджинской групп, при применении данного метода визуализации, фиксируется очень рано проявляющийся комплекс расовых признаков (Рогинский, 1960), который отчетливо читается именно на цифровых портретных фотообобщениях. Наблюдаемый феномен иллюстрирует переход от индивидуально-типологического уровня к популяционному видению реальности. Именно на этом уровне срабатывает метод обобщенного фотопортрета, выявляя на любом произвольно выбранном возрастном интервале онтогенеза четко распознаваемые морфологические комплексы элементов внешности.

Полученные нами фотообобщения тоджинцев и сборной группы из других районов Тувы и обследованных в Кызыле, как у мальчиков, так и у девочек соответствующих возрастных когорт, практически неразличимы между собой. Данный результат позволяет делать заключение о значительной гомогенности обследованных тувинских групп в настоящее время. Антропологический вариант, представленный полученной серией обобщенных фотопортретов, узнаваем и соответствует классической характеристике центрально-азиатского расового типа (Левин, 1958: 306).

\section{Заключение}

Резюмируя все вышесказанное, можно заключить, что динамика изменений размеров головы и лица тувинских детей и подростков обоего пола, проживающих в столице Республики Тыва и в Тоджин- 
ском районе, соответствует общебиологическим закономерностям. Это проявляется в относительно небольшой интенсивности изменчивости большинства показателей, демонстрирующих увеличение на протяжении возрастного ряда (за исключением головного указателя). Что касается межпоколенных различий, то они также не так велики, поэтому основные параметры головы и лица, присущие тувинскому этносу, сохраняются на протяжении прошедших со времени последнего обследования десятилетий. Полученные результаты позволяют заключить, что только продольный диаметр головы дает незначительный вклад в трансформацию расового и этнического облика населения. Сохранение классических характеристик центрально-азиатского типа подтверждают результаты фотообобщений, что также свидетельствует о значительной гомогенности обследованных тувинских групп в настоящее время.

\section{СПИСОК ЛИТЕРАТУРЫ}

Аксянова, Г. А. (2009) Основные результаты расогенетических исследований в Туве в XX столетии (обзор литературных источников) // Археология, этнография и антропология Евразии. № 4 (40). С. 137-145.

Алексеева, Т. И. (1984) Антропологические особенности современных тувинцев. Кефалометрия и кефалоскопия // Антропоэкологические исследования в Туве / отв. ред. Т. И. Алексеева, М. И. Урысон. М. : Наука. 224 с. C. $75-114$.

Алексеева, Т. И. (1986) Адаптивные процессы в популяциях человека. М. : МГУ. 215 с.

Антропоэкологические исследования в Туве (1984) / отв. ред. Т. И. Алексеева, М. И. Урысон. М. : Наука. 224 с.

Антропоэкология Центральной Азии (2005) / под ред. Т. И. Алексеевой, В. А. Бацевича, Р. М. Мунчаева, О. П. Павловского, В. В. Прохорова, В. А. Спицына. М. : Научный мир. 326 с.

Анайбан, 3. В. (2009) Социально-экономические процессы в регионах Южной Сибири и условия адаптации населения к новым условиям жизни [Электронный ресурс] // Новые исследования Тувы. № 1-2. C. 65-90. URL: https://nit.tuva.asia/nit/article/view/654 (дата обращения: 25.09.2020).

Анайбан, 3. В. (2010) Социальная адаптация населения Тувы к современным экономическим преобразованиям // Управление ресурсным потенциалом регионов на базе геоинформационных технологий / отв. ред. В. И. Лебедев, Е. А. Мамаш. Кызыл : ТувИКОПР. 138 с. С. 45-52.

Ауль, Ю. М. (1964) О некоторых закономерностях роста головы у детей школьного возраста // Современная антропология. Московское общество испытателей природы. Секция антропологии. Труды МОИП. T. XIV. М. : Изд-во МГУ. 304 с. С. $19-25$

Бацевич, В. А. (2016) Секулярная и возрастная динамика биологических характеристик в двух группах современного населения в разных экологических условиях // Вестник Московского университета. Серия 23. Антропология. № 4. С. 110-117.

Бацевич, В. А., Бутовская, М. Л., Кобылянский, Е. (2018) Адаптивный статус, темпы онтогенеза и динамика морфологических признаков в трех скотоводческих популяциях, сохранивших традиционный образ жизни // Вестник Московского университета. Серия XXIII. Антропология. № 3. С. 5-20. DOI: https://doi.org/10.32521/20748132.2018.3.005-020

Бацевич, В. А., Машина, Д. А., Пермякова, Е. Ю. (2020) Социально-экономические преобразования на территории Тувы и изменения адаптивных биологических характеристик у коренного населения // Вестник Московского университета. Серия XXIII. Антропология. № 4. В печати.

Бацевич, В. А., Красильникова, В. А., Пермякова, Е. Ю. (2020) Адаптационные возможности студентов из разных районов Республики Тыва // Вестник Московского университета. Серия XXIII. Антропология. № 3. С. 19-31. DOI: 10.32521/2074-8132.2020.3.019-031

Бацевич, В. А., Ясина, О. В. (2000) Темпы онтогенеза у населения Монголии // Вопросы антропологии. Вып. 90. C. $104-114$.

Богданова, В. И. (1986) Антропологический состав и вопросы происхождения тувинцев // Проблемы антропологии древнего и современного населения Советской Азии / отв. ред. В. П. Алексеев. Новосибирск : Наука. 191 с. С. $108-162$.

Богданова, В. И., Халдеева, Н. И. (1980) Однотологические признаки у тувинцев // Современные проблемы и новые методы в антропологии / отв. ред. И. И. Гохман. Л. : Наука. 200 с. С. 184-195.

Будилова, Е. В., Лагутин, М. Б., Мигранова Л. А. (2015) Динамика популяционного здоровья населения России (2005-2013 гг.) // Народонаселение. № 3. С. 99-110.

Бунак, В. В. (1960) Лицевой скелет и факторы, определяющие вариации его строения // Антропологический сборник II (ТИЭ. Новая серия. Т. L) / отв. ред. Г. Ф. Дебец, М. Г. Левин. М. : Изд-во АН СССР. 232 с. С. 84-152.

Вайнштейн, С. И. (1961) Тувинцы-тоджинцы. Историко-этнографические очерки. М. : Издательство Восточной литературы. 218 с. 
Волкова, Т. В. (1988) Акселерация населения СССР. М. : Изд-во МГУ. 70 с.

Година, Е. 3. (2010) Некоторые проблемы современной ауксологии человека и пути их решения (по материалам исследований НИИ и Музея антропологии МГУ) // Вестник Московского университета. Серия XXIII. Антропология. № 3. С. 4-15.

Козлов, А. И., Вершубская, Г. Г., Лисицин, Д. В., Санина, Е. Д., Атеева, Ю. А. (2009) Пермские и волжские финны: медицинская антропология в экологической перспективе. Пермь : АрктАн-С. 160 с. $360 \mathrm{c}$.

Левин, М. Г. (1958) Этническая антропология и проблемы этногенеза народов Дальнего Востока. М. : Наука.

Маурер, А. М., Сыроежкин, Г. В. (2015) Расширенные возможности метода обобщенного фотопортрета (три евразийские выборки) // Антропология в Московском университете: к юбилею МГУ : сборник научных статей / отв. ред. А. П. Бужилова. М. : НИИ и Музей антропологии МГУ Москва. С. 81-93.

Миклашевская, Н. Н. (1973) Рост головы и лица у детей и подростков // Рост и развитие ребенка / отв. ред. Н. Н. Миклашевская. М. : Издательство Московского университета. 220 с. С. 55-88.

Негашева, М. А. (2017) Основы антропометрии: учебное пособие. М. : Экон-Информ. 216 с.

Перевозчиков, И. В. (1987) Основы антропологической фотографии. М. : МГУ. 60 с.

Перевозчиков, И. В., Маурер, А. М. (2009) Обобщенный фотопортрет: история, методы, результаты // Вестник Московского университета. Серия 23: Антропология. № 1. С. 35-44.

Рогинский, Я. Я. (1960) К вопросу о возрастных изменениях расовых признаков у человека (в утробном периоде и в детстве) // Труды Института этнографии имени Н. И. Миклухо-Маклая. Новая серия. М. ; Ленинград : Академия наук СССР. Т. 50. С. 3-28.

Савинецкий, А. Б., Низаметдинов, Ш. У., Сыроежкин, Г. В., Сафиуллин А. Э. (2015) Разработка методов создания и обработки обобщенных компьютерных изображений и их приложение в антропологии // Научная визуализация. T. 7. № 5. C. 53-67.

Ярхо, А. И. (1929) Антропологический тип кемчикских танну-тувинцев // Северная Азия. Кн. 5/6. С. $127-132$.

Ярхо, А. И. (1936) Краткий обзор антропологического изучения турецких народностей за 10 лет (1924-1934) // Антропологический журнал. № 1. С. 47-64.

Ярхо, А. И. (1947) Алтае-саянские тюрки. Антропологический очерк. Абакан : Хакоблнациздат. 148 с.

Barker, D. J., Thornburg, K. L. (2013) Placental programming of chronic diseases, cancer and lifespan: a review // Placenta. Vol. 34 (10). Pp. 841-845. DOI: https://doi.org/10.1016/j.placenta.2013.07.063

Brüne, M., Hochberg, Z. (2013) Secular trends in new childhood epidemics: insights from evolutionary medicine // BMC Med. Vol. 11. P. 226. DOI: https://doi.org/10.1186/1741-7015-11-226

Bunak, V. V. (1928) Le Tannou-Touva // Internationales Archiv fur Ethnographie. 29. P. 1-16.

Eriksson, S., Graf, E. H., Dahl, V., Strain, M. C., Yukl, S. A., Lysenko, E. S., Bosch, R. J., Lai, J., Chioma, S., Emad, F., AbdelMohsen, M., Hoh, R., Hecht, F., Hunt, P., Somsouk, M., Wong, J., Johnston, R., Siliciano, R. F., Richman, D. D., O'Doherty, U., Palmer, S., Deeks, S. G., Siliciano, J. D. (2013) Comparative analysis of measures of viral reservoirs in HIV-1 eradication studies // PLoS Pathog. Vol. 9 (2). e1003174. DOI: https://doi.org/10.1371/journal.ppat.1003174

Galton, Fr. (1878) Composite portraits // Journal of the Anthropological Institute of Great Britain and Ireland. Vol. 8. P. 132-142.

Hermanussen, M. (2013) Auxology. Studying human growth and development. Schweizerbart : Stuttgart. 324 p.

Katzmarzyk, P. T., Leonard, W. R. (1998) Climatic influences on human body size and proportions: Ecological adaptations and secular trends //American Journal of Physical Anthropology. Vol. 106. № 4. P. 483-503.

Malina, R. M. (2004) Secular trends in growth, maturation and physical performance: A review // Przegląd Antropologiczny - Anthropological Review. Vol. 67. P. 3-31.

Miklashevskaya, N. N. (1966) Growth of the head and face in boys of various ethnic groups in the USSR // Human Biology. Vol. 38. Pp. 231-250.

Miklashevskaya, N. N. (1969) Sex differences in growth of the head and face in children and adolescents // Human Biology. Vol. 41. Pp. 250-262.

Shephard, R. J., Rode, A. (1996) The Health Consequences of 'Modernization': Evidence from Circumpolar Peoples. Cambridge University Press. 306 p.

Дата поступления: 28.09.2020 г.

\section{REFERENCES}

Aksianova, G. A. (2009) Osnovnye rezul'taty rasogeneticheskikh issledovanii v Tuve v KhKh stoletii (obzor literaturnykh istochnikov) [Principal findings of the $20^{\text {th }}$ century population studies in Tuva: a survey of sources]. Arkheologiia, etnografiia i antropologiia Evrazii, no. 4 (40), pp. 137-145. (In Russ.).

Alekseeva, T. I. (1984) Antropologicheskie osobennosti sovremennykh tuvintsev. Kefalometriia i kefaloskopiia [Anthropological features of modern Tuvans. Cephalometry and cephaloscopy]. In: Antropo-ekologicheskie issledovaniia 
$v$ Tuve [Anthropoecological research in Tuva]. Ed. by T. I. Alekseeva and M. I. Uryson. Moscow, Nauka. 224 p. Pp. 75-114. (In Russ.).

Alekseeva, T. I. (1986) Adaptivnye protsessy v populiatsiiakh cheloveka [Adaptive processes in human populations]. Moscow, MGU. 215 p. (In Russ.).

Antropoekologicheskie issledovaniia v Tuve [Anthropoecological research in Tuva] (1984) / ed. by T. I. Alekseeva and M. I. Uryson. Moscow, Nauka. 224 p. (In Russ.).

Antropoekologiia Tsentral'noi Azii [Anthropoecology of Central Asia] (2005) ed. by T. I. Alekseeva, V. A. Batsevich, R. M. Munchaev, O. P. Pavlovsky, V. V. Prokhorov and V. A. Spitsyn. Moscow, Nauchnyi mir. 326 p. Pp. 6-126. (In Russ.).

Anaiban, Z. V. (2009) Sotsial'no-ekonomicheskie protsessy v regionakh Iuzhnoi Sibiri i usloviia adaptatsii naseleniia k novym usloviiam zhizni [Social and economic processes in South Siberian regions and conditions of adapting to the new conditions of life]. New Research of Tuva, no. 1-2, pp. 65-90 [online] Available at: https://nit.tuva.asia/nit/article/view/654 (access date: 25.09.2020) (In Russ.).

Anaiban, Z. V. (2010) Sotsial'naia adaptatsiia naseleniia Tuvy k sovremennym ekonomicheskim preobrazovaniiam [Social adaptation of the population of Tuva to modern economic transformations]. In: Upravlenie resursnym potentsialom regionov na baze geoinformatsionnykh tekhnologii [Management of the resource potential of regions based on geoinformation technologies] / ed. by V. I. Lebedev and E. A. Mamash. Kyzyl, TuvIKOPR. 138 p. Pp. 45-52. (In Russ.).

Aul', Yu. M. (1964) O nekotorykh zakonomernostiakh rosta golovy u detei shkol'nogo vozrasta [Some patterns of head growth in schoolchildren]. In: Sovremennaia antropologiia. Moskovskoe obshchestvo ispytatelei prirody. Sektsiia antropologii. Trudy MOIP [Modern anthropology. Moscow Society of Naturalists. Section of Anthropology. Proceedings of MOIP]. Moscow, Izd-vo MGU. Vol. IV. 304 p. Pp. 19-25. (In Russ.).

Batsevich, V. A. (2016) Sekuliarnaia i vozrastnaia dinamika biologicheskikh kharakteristik v dvukh gruppakh sovremennogo naseleniia v raznykh ekologicheskikh usloviiakh [Secular and age changes of biological characteristics in two groups of modern population in different ecological environment]. Vestnik Moskovskogo universiteta. Seriia 23. Antropologiia, no. 4, pp. 110-117. (In Russ.).

Batsevich, V. A., Butovskaia, M. L. and Kobylianskii, E. (2018) Adaptivnyi status, tempy ontogeneza i dinamika morfologicheskikh priznakov $\mathrm{v}$ trekh skotovodcheskikh populiatsiiakh, sokhranivshikh traditsionnyi obraz zhizni [Rates of ontogenesis, dynamics of morphological changes and adaptive status in three present-day pastoral populations, retaining traditional way of living]. Vestnik Moskovskogo universiteta. Seriia XXIII. Antropologiia, no. 3, pp. 5-20. (In Russ.). DOI: https://doi.org/10.32521/2074-8132.2018.3.005-020

Batsevich, V. A., Mashina, D. A. and Permiakova, E. Yu. (2020) Sotsial'no-ekonomicheskie preobrazovaniia na territorii Tyvy i izmeneniia adaptivnykh biologicheskikh kharakteristik u korennogo naseleniia [Socio-economic transformations on the territory of Tuva and changes in adaptive biological characteristics of the indigenous population]. Vestnik Moskovskogo universiteta. Seriia XXIII. Antropologiia, no. 4. In press (In Russ.).

Batsevich, V. A., Krasil'nikova, V. A. and Permiakova, E. Yu. (2020) Adaptatsionnye vozmozhnosti studentov iz raznykh raionov Respubliki Tyva [Adaptation capabilities of students from different regions of The Republic of Tuva]. Vestnik Moskovskogo universiteta. Seriia XXIII. Antropologiia, no. 3, pp. 19-31. (In Russ.). DOI: 10.32521/2074-8132.2020.3.019-031

Batsevich, V. A. and Iasina, O. V. (2000) Tempy ontogeneza u naseleniia Mongolii [Rates of ontogenesis in the population of Mongolia]. Voprosy antropologii, vol. 90, pp. 104-114. (In Russ.).

Bogdanova, V. I. (1986) Antropologicheskii sostav i voprosy proiskhozhdeniia tuvintsev [Anthropological composition and questions of the origin of Tuvans]. In: Problemy antropologii drevnego i sovremennogo naseleniia Sovetskoi Azii [Problems of anthropology of the ancient and modern population of Soviet Asia] / ed. by V. P. Alekseev. Novosibirsk, Nauka. 191 p. Pp. 108-162. (In Russ.).

Bogdanova, V. I. and Khaldeeva, N. I. (1980) Odnotologicheskie priznaki u tuvintsev [Monotological signs among Tuvans]. In: Sovremennye problemy i novye metody v antropologii [Modern problems and new methods in anthropology] / ed. by I. I. Gokhman. Leningrad, Nauka. 200 p. Pp. 184-195. (In Russ.).

Budilova, E. V., Lagutin, M. B. and Migranova L. A. (2015) Dinamika populiatsionnogo zdorov'ia naseleniia Rossii (2005-2013 gg.) [Dynamics of population health in Russia in 2005-2013]. Narodonaselenie, no. 3, pp. 99-110. (In Russ.).

Bunak, V. V. (1960) Litsevoi skelet i faktory, opredeliaiushchie variatsii ego stroeniia [Facial skeleton and factors determining variations in its structure]. Antropologicheskii sbornik II [Anthropological collection II] / TIE. Novaia seriia. T. L / ed. by G. F. Debets and M. G. Levin. Moscow, AN SSSR Publ. 232 p. Pp. 84-152. (In Russ.).

Vainshtein, S. I. (1961) Tuvintsy-todzhintsy. Istoriko-etnograficheskie ocherki [Tozhu tuvans: historical and ethnographic essays]. Moscow, Nauka. 218 p. (In Russ.).

Volkova, T. V. (1988) Akseleratsiia naseleniia SSSR [Developmental acceleration of the population of the USSR]. Moscow, MGU Publ. 70 p. (In Russ.).

Godina, E. Z. (2010) Nekotorye problemy sovremennoi auksologii cheloveka i puti ikh resheniia (po materialam issledovanii NII i Muzeia antropologii MGU) [Some problems of modern auxology and related studies at the Institute and Museum of Anthropology, Lomonosov Moscow State University: a review]. Vestnik Moskovskogo universiteta. Seriia XXIII. Antropologiia, no. 3, pp. 4-15. (In Russ.). 
Kozlov, A. I., Vershubskaia, G. G., Lisitsin, D. V., Sanina, E. D. and Ateeva, Yu. A. (2009) Permskie i volzhskie finny: meditsinskaia antropologiia $v$ ekologicheskoi perspective [Perm and Volga Finns: Medical anthropology from an ecological perspective]. Perm', ArktAn-S. 160 p. (In Russ.).

Levin, M. G. (1958) Etnicheskaia antropologiia i problemy etnogeneza narodov Dal'nego Vostoka [Ethnic anthropology and problems of ethnogenesis of the peoples of the Far East]. Moscow, Nauka. 360 p. (In Russ.).

Maurer, A. M. and Syroezhkin, G. V. (2015) Rasshirennye vozmozhnosti metoda obobshchennogo fotoportreta (tri evraziiskie vyborki) [Enhancing the potential of composite photo portrait: A case study of three Eurasian samples]. In: Antropologiia v Moskovskom universitete: $k$ iubileiu MGU [Anthropology at Moscow University: to the anniversary of Moscow State University] : collection of scientific articles / ed. by A. P. Buzhilova. Moscow, Research Institute and Museum of Anthropology Moscow State University Moscow]. Pp. 81-93. (In Russ.).

Miklashevskaia, N. N. (1973) Rost golovy i litsa u detei i podrostkov [Head and face growth in children and adolescents]. In: Rost i razvitie rebenka [Growth and development of children] / ed. by N. N. Miklashevskaia. Moscow, Izdatel'stvo Moskovskogo universiteta. 220 p. Pp. 55-88. (In Russ.).

Negasheva, M.A. (2017) Osnovy antropometrii [Foundations of anthropometry]. Moscow, Ekon-Inform. 216 p. (In Russ.).

Perevozchikov, I. V. (1987) Osnovy antropologicheskoi fotografii [Fundamentals of anthropological photography]. Moscow, MGU. 60 p. (In Russ.).

Perevozchikov, I. V. and Maurer, A. M. (2009) Obobshchennyi fotoportret: istoriia, metody, rezul'taty [Composite photo portraits: history, methods, results]. Vestnik Moskovskogo universiteta. Seriia 23: Antropologiia, no. 1, pp. 35-44. (In Russ.).

Roginskii, Ya. Ya. (1960) K voprosu o vozrastnykh izmeneniiakh rasovykh priznakov u cheloveka (v utrobnom periode i v detstve) [On the issue of age-related changes in human racial characteristics in uterine period and in childhood]. Trudy Instituta etnografii imeni N. I. Miklukho-Maklaia. Novaia seriia. Moscow, Leningrad, akad. Nauk SSSR. Vol. 50. Pp. 3-28. (In Russ.).

Savinetskii, A. B., Nizametdinov, Sh. U., Syroezhkin, G. V. and Safiullin A. E. (2015) Razrabotka metodov sozdaniia i obrabotki obobshchennykh komp'iuternykh izobrazhenii i ikh prilozhenie v antropologii [Developing methods for creating and analyzing of generalized digital images and their application in anthropology]. Nauchnaia vizualizatsiia, vol. 7, no. 5, pp. 53-67. (In Russ.).

Yarkho, A. I. (1929) Antropologicheskii tip kemchikskikh tannu-tuvintsev [Anthropological type of the Kemchik TannuTuvans]. Severnaia Aziia [Northern Asia], book 5/6, pp. 127-132. (In Russ.).

Yarkho, A.I. (1936) Kratkii obzor antropologicheskogo izucheniia turetskikh narodnostei za 10 let (1924-1934) [A brief overview of the anthropological study of Turkish peoples in 10 years (1924-1934)]. Antropologicheskii zhurnal, no. 1, pp. 47-64. (In Russ.).

Yarkho, A. I. (1947) Altae-saianskie tiurki. Antropologicheskii ocherk [Altai-Sayan Turks: An anthropological essay]. Abakan, Khakoblnatsizdat. 148 p. (In Russ.).

Barker, D. J. and Thornburg, K. L. (2013) Placental programming of chronic diseases, cancer and lifespan: a review. Placenta, vol. 34 (10), pp. 841-845. DOI: doi.org/10.1016/j.placenta.2013.07.063

Brüne, M. and Hochberg, Z. (2013) Secular trends in new childhood epidemics: insights from evolutionary medicine. BMC Med., vol. 11, p. 226. DOI: doi.org/10.1186/1741-7015-11-226

Bunak, V. V. (1928) Le Tannou-Touva. In: Internationales Archiv fur Ethnographie. Bd. 29. Pp. 1-16. (In Deuch).

Eriksson, S., Graf, E.H., Dahl, V., Strain, M. C., Yukl, S. A., Lysenko, E. S., Bosch, R. J., Lai, J., Chioma, S., Emad, F., AbdelMohsen, M., Hoh, R., Hecht, F., Hunt, P., Somsouk, M., Wong, J., Johnston, R., Siliciano, R. F., Richman, D. D., O'Doherty, U., Palmer, S., Deeks, S. G. and Siliciano, J. D. (2013) Comparative analysis of measures of viral reservoirs in HIV-1 eradication studies. PLoS Pathog, vol. 9 (2). DOI: doi.org/10.1371/journal.ppat.1003174

Galton, Fr. (1878) Composite portraits. Journal of the Anthropological Institute of Great Britain and Ireland, vol. 8, pp. 132-142.

Hermanussen, M. (2013) Auxology. Studying human growth and development. Schweizerbart, Stuttgart. 324 p.

Katzmarzyk, P. T. and Leonard, W. R. (1998) Climatic influences on human body size and proportions: Ecological adaptations and secular trends. American Journal of Physical Anthropology, vol. 106, no. 4, pp. 483-503.

Malina, R. M. (2004) Secular trends in growth, maturation and physical performance: A review. Przegląd Antropologiczny - Anthropological Review, vol. 67, pp. 3-31.

Miklashevskaya, N. N. (1966) Growth of the head and face in boys of various ethnic groups in the USSR. Human Biology, vol. 38, pp. 231-250.

Miklashevskaya, N. N. (1969) Sex differences in growth of the head and face in children and adolescents. Human Biology, vol. 41, pp. 250-262.

Shephard, R. J. and Rode, A. (1996) The Health Consequences of 'Modernization': Evidence from Circumpolar Peoples. Cambridge University Press. 306 p.

Submission date: 28.09 .2020 